\title{
HIGH-FAT DIET INCREASES SERUM HDL, BUT NOT FOR LDL AND HDL/LDL RATIO IN MICE
}

\author{
Iqbal Laksana ${ }^{1}$, Purwo Sri Rejeki $^{2,3}$, Lilik Herawati ${ }^{2,3}$, Mohammad Anam Al Arif ${ }^{4}$, Indrayuni Lukitra \\ Wardhani ${ }^{5}$ \\ ${ }^{1}$ Medical Program, Faculty of Medicine, Universitas Airlangga, Surabaya, Indonesia \\ ${ }^{2}$ Department of Physiology, Faculty of Medicine, Universitas Airlangga, Surabaya, Indonesia \\ ${ }^{3}$ Health Science Program, Faculty of Medicine, Universitas Airlangga, Surabaya, Indonesia \\ ${ }^{4}$ Department of Animal Husbandry, Faculty of Veterinary Medicine, Universitas Airlangga \\ ${ }^{5}$ Department of Physical Medicine and Rehabilitation, Faculty of Medicine, Universitas Airlangga, Surabaya, \\ Indonesia/Medical Rehabilitation, Siloam Hospital, Surabaya, Indonesia
}

\begin{abstract}
The use of ketogenic diet with an increased proportion of fat is rampant lately, both as a therapy or even lifestyle. The use of ketogenic diet is feared to cause dyslipidemia and will lead atherosclerosis and thrombosis. This study aimed to determine effect of high-fat diet on HDL, LDL and HDL/LDL ratio in mice. Thirty male Mus Musculus, 2-3 mo, 15-25 g divided into five groups diet. K1 (12\% fat, 20\% protein, 62\% carb), K2 (30\% fat, 60\% protein), K3 (45\% fat, 45\% protein), K4 (60\% fat, $30 \%$ protein) and $K 5$ (75\% fat, 15\% protein) for 4 weeks. Feed and water by adlibitum. Blood for serum was taken from ventricle, while the measurement of serum level of HDL, LDL used ELISA. Normality of data analyzed by Saphiro Wilk, and homogeneity by Levene test. HDL serum was analyzed using equality test followed by Games Howell, LDL serum and ratio of HDL/LDL was tested by Anova followed by LSD with significance 0,05. HDL serum in $K 1(62,50 \pm 9.94) \mathrm{mg} / \mathrm{dL}, \mathrm{K} 2(78,40 \pm 18,76) \mathrm{mg} / \mathrm{dL}, \mathrm{K} 3$ $(79,00 \pm 3,81) \mathrm{mg} / \mathrm{dL}, \mathrm{K} 4(80,00 \pm 2,16) \mathrm{mg} / \mathrm{dL}$, and $\mathrm{K} 5(83,50 \pm 5,62) \mathrm{mg} / \mathrm{dL}$ with $\mathrm{p}<0,05$ in $\mathrm{Kl}, \mathrm{K} 2$ to $\mathrm{K} 3, \mathrm{~K} 4$ and $\mathrm{K5}$. LDL serum in $K 1(21,67 \pm 4,80) \mathrm{mg} / \mathrm{dL}, K 2(23,00 \pm 12,70) \mathrm{mg} / \mathrm{dL}, \mathrm{K} 3(18,40 \pm 4,34) \mathrm{mg} / \mathrm{dL}, K 4(24,00 \pm 1,83) \mathrm{mg} / \mathrm{dL}$ and $\mathrm{K} 5(22,00 \pm 4,08)$

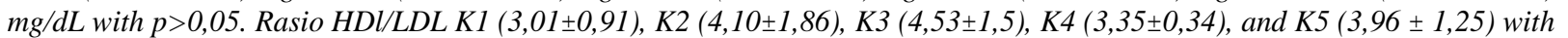
$p>0,05$.
\end{abstract}

Keywords: high fat diet; mice; HDL; LDL; HDL/LDL ratio; obesity

\section{ABSTRAK}

Penggunaan diet ketogenik dengan peningkatan proporsi lemak akhir-akhir ini semakin populer, baik sebagai terapi ataupun gaya hidup. Penggunaan diet ketogenik dikhawatirkan menyebabkan dislipidemia dan akan menyebabkan aterosklerosis dan trombosis. Tujuan dari penelitian ini adalah untuk mengetahui pengaruh diet tinggi lemak pada rasio HDL, LDL dan HDL/LDL pada tikus. Tiga puluh Mus Musculus jantan, usia 2-3 bulan, 15-25 gram dikelompokan kedalam lima kelompok diet. K1 (12\% lemak, 20\% protein, 62\% karbohidrat), K2 (30\% lemak, 60\% protein), K3 (45\% lemak, $45 \%$ protein), K4 (60\% lemak, $30 \%$ protein) and $\mathrm{K} 5(75 \%$ lemak, $15 \%$ protein) selama empat minggu. Pakan dan air secukupnya. Normalitas data dianalisis dengan Shapiro Wilk, sedangkan homogenitas dengan uji Levene. Serum HDL dianalisis dengan uji kesetaraan dan Games Howell. LDL serum dan rasio HDL/LDL diuji oleh Anova dan LSD dengan signifikansi 0,05. Serum HDL pada K1

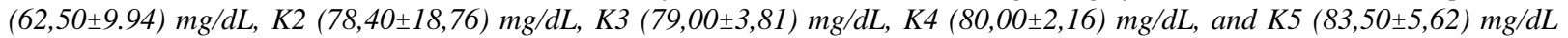
dengan $p<0,05$ pada K1, K2 to K3, K4 and K5. Serum LDL pada K1 $(21,67 \pm 4,80) m g / d L, K 2(23,00 \pm 12,70) m g / d L, K 3$ $(18,40 \pm 4,34) \mathrm{mg} / \mathrm{dL}, K 4(24,00 \pm 1,83) \mathrm{mg} / \mathrm{dL}$ and $K 5$ (22,00 \pm 4,08) $\mathrm{mg} / \mathrm{dL}$ dengan $\mathrm{p}>0,05$. Rasio HDl/LDL K1 (3,01 $\pm 0,91)$, $K 2(4,10 \pm 1,86), K 3(4,53 \pm 1,5), K 4(3,35 \pm 0,34)$, and $K 5(3,96 \pm 1,25)$ dengan $p>0,05$.

Kata kunci: high fat diet; tikus; $H D L ; L D L ;$ rasio $H D L / L D L ;$ obesitas

Correspondence: Purwo Sri Rejeki, Department of Physiology, Faculty of Medicine, Universitas Airlangga / Health Science Program, Faculty of Medicine, Universitas Airlangga. Email: purwo_faal@yahoo.com; purwo-sr@fk.unair.ac.id

pISSN:2355-8393 • eISSN: 2599-056x • doi: 10.20473/fmi.v57i2.16123

- Fol Med Indones. 2021;57:117-120 • Received 13 Nov 2019 • Accepted 07 Jan 2021

- Open access under CC-BY-NC-SA license • Available at https://e-journal.unair.ac.id/FMI/ 


\section{INTRODUCTION}

Nowadays, obesity is one of serious problems around the world. Its prevalence increases every year (Oyekale 2019). In 2013, Indonesia had a prevalence of obesity reached $26 \%$ of the total population of Indonesia (Ministry of Health 2013). The ketogenic diet is one of methods that requires people to change their eating habits with special rules (Masood et al 2020). In the ketogenic diet, a person will consume foods with high in fat and protein, but very low in carbohydrates (Kosinki \& Jomayvaz 2017). The ketogenic diet initially only became a non-pharmacological therapy for people with epilepsy, but it is now widely used as a therapy for obese patients (Paoli et al 2013), diabetes mellitus and cancer. Now, this diet even leads to a lifestyle.

The high proportion of fat in the ketogenic diet raises a polemic, especially an increasing risk of cardiovascular disease. High fat is thought will trigger dyslipidemia as the pathophysiology of atherosclerosis. The ketogenic diet leads physiological process of ketosis (Paoli et al 2013). In many ketogenic diet using as therapy, there is an increase high density lipoprotein (HDL), and a decrease low density lipoprotein (LDL) blood (Dashti 2004). High HDL and low LDL level affect the risk of cardiovascular diseases, such as atherosclerosis ( $\mathrm{Hu} \&$ Bazzano 2015). However, the proportion of energy sources in this diet that influences HDL and LDl levels in the blood has not been revealed clearly. This study was to determine the effect of the proportion of energy sources in a high-fat diet on HDL and LDL levels.

\section{MATERIALS AND METHODS}

This study had been approved by the Committee of Animal Care and Use, Faculty of Veterinary Universitas Airlangga under a decree No 2.KE.124.07.2018. The design of the study was posttest only control group design conducted at the Faculty of Veterinary Medicine, Universitas Airlangga during December 2018 to February 2019.

Fifty male Mus Musculus balb/c, 2-3 aged month, 120150 gram, and acclimatized for one week. Mice were divided into 5 groups; K1 (control, $12 \%$ fat, $20 \%$ protein, $62 \%$ carbohydrate), $\mathrm{K} 2$ (30\% fat, $60 \%$ protein, $0 \%$ carbohydrate), K3 (45\% fat, $45 \%$ protein, $0 \%$ carbohydrate), K4 (60\% fat, $30 \%$ protein, $0 \%$ carbohydrate) and K5 (75\% fat, $15 \%$ protein, $0 \%$ carbohydrate). Diet was administrated for 4 weeks; ad libitum and mice were purified. Body weight weighed before and after treatment. Serum was obtained from the blood taken from the ventricle. The measurement of HDL and LDL levels was using ELISA. The serum obtained when less than $1.5 \mathrm{ml}$ was not refractive in HDL and LDL measurement.

The data were analyzed using SPSS included normality test using Saphiro Wilk ( $>0.05)$, and homogeneity using Brown-Forsythe robust homogeneity test $(\mathrm{p}<0,05)$, Anova, and post Hoc using Games Howell test.

\section{RESULTS}

The initial number of mice before diet treatment was 50 . Some mice died during study took place. Weight before and after 4 weeks of feeding can be seen in Table 1. In addition to the samples excommunicated due to death, the samples were also excommunicated due to other factors, such as blood volume that was insufficient to be able to perform HDL and LDL measurements.

Table 1. Body weight in pre and posttest

\begin{tabular}{llll}
\hline Group & $\mathbf{n}$ & $\begin{array}{l}\text { Pre BW (gram) } \\
\mathbf{X} \pm \text { SD }\end{array}$ & $\begin{array}{l}\text { Post BW (gram) } \\
\mathbf{X} \pm \text { SD }\end{array}$ \\
\hline K1 & 9 & $23.56 \pm 2.46$ & $26.22 \pm 4.66$ \\
K2 & 5 & $27.20 \pm 2.39$ & $21.40 \pm 3.65$ \\
K3 & 5 & $24.00 \pm 4.24$ & $14.40 \pm 3.78$ \\
K4 & 4 & $24.00 \pm 3.37$ & $14.25 \pm 2.06$ \\
K5 & 4 & $26.50 \pm 1.30$ & $18.00 \pm 1.16$ \\
\hline
\end{tabular}

Table 1 showed that overall mice at $\mathrm{K} 2-\mathrm{K} 5$ group occurred weight loss, while at $\mathrm{K} 1$ the body weight increased.

Table 2. Table 2. Serum HDL, LDL, HDL/LDL ratio

\begin{tabular}{|c|c|c|c|c|}
\hline Group & $\mathrm{n}$ & $\begin{array}{c}\text { HDL }(\mathbf{m g} / \mathbf{d L}) \\
\quad \mathrm{X} \pm \mathrm{SD}\end{array}$ & $\begin{array}{c}\mathbf{L D L} \\
(\mathbf{m g} / \mathbf{d L}) \\
\mathbf{X} \pm \mathbf{S D}\end{array}$ & $\underset{\text { ratio }}{\text { HDL/LDL }}$ \\
\hline K1 & 9 & $62,50 \pm 9.94^{\mathrm{a}}$ & $\begin{array}{c}21,67 \pm \\
4,80^{\mathrm{a}}\end{array}$ & $3,01 \pm 0,91^{\mathrm{a}}$ \\
\hline K2 & 5 & $78,40 \pm 18,76^{a}$ & $\begin{array}{c}23,00 \pm \\
12,7^{\mathrm{a}}\end{array}$ & $4,10 \pm 1,86^{\mathrm{a}}$ \\
\hline K3 & 5 & $79,00 \pm 3,81^{b}$ & $\begin{array}{c}18,40 \pm \\
4,34^{\mathrm{a}}\end{array}$ & $4,53 \pm 1,25^{\mathrm{a}}$ \\
\hline K4 & 4 & $80,00 \pm 2,16^{\mathrm{b}}$ & $\begin{array}{c}24,00 \pm \\
1,83^{\mathrm{a}}\end{array}$ & $3,35 \pm 0,34^{a}$ \\
\hline K5 & 4 & $83,50 \pm 5,62^{\mathrm{b}}$ & $\begin{array}{c}22,00 \pm \\
4,08^{\mathrm{a}}\end{array}$ & $3,96 \pm 1,25^{\mathrm{a}}$ \\
\hline
\end{tabular}

HDL and LDL measurement results, HDL/LDL ratio could be seen in Table 2 . There was no significant difference in HDL serum between $\mathrm{K} 1$ and $\mathrm{K} 2$, but different from K3, K4 and K5. Yet, this difference did not happen to LDL and HDL/LDL ratio. There were no differences among K1-K5. 


\section{DISCUSSION}

This study also purposed to know the effect of nutrient composition on high fat diet to these parameters. High fat diet (the ketogenic diet) in K3-K5 was increasing HDL serum, but not in K2. This result was in line with a study conducted by Dashti et al (2004) and Salvador et al (2021) which revealed that the ketogenic diet had an effect on increasing HDL levels. The ketogenic diet which was commonly called as a high-fat and lowcarbohydrate diet had provided a significant increase in HDL levels (Lima et al 2015). When undergoing ketogenic diet treatment, the body would be in ketosis state (Jensen et al 2020).

The state of ketosis continuous glucose and insulin level might be low, which lowered lipoprotein lipase (LPL) and increased hormone sensitive lipase (HSL), encouraged an increased triacylglycerol hydrolysis (TAG) and fatty acids. The increased free fatty acids would be taken by the liver then diverted from esterification to TAG and towards oxidation of mitochondria to acetyl-CoA. The accumulation of acetyl-CoA that exceeded the capacity would then be converted into a ketone body. The reduction of TAG production in the liver resulted in the effect of secretion of VLDL in the decreased circulation. The lipolysis VLDL mediated by LPL results in transfer of unesterified cholesterol, phospholipid (PL), apolipoprotein (apo) E, apoC-II, and apoC-III to form mature HDL-C. The remaining particles were taken by the liver or converted to LDL (Volek et al 2005).

The results of this study regarding the effect of the ketogenic diet on LDL levels carried out for one month did not have a significant effect for both clinically and statistically. LDL levels in all groups were not much different and tend to be the same. Giving the ketogenic diet less than three months would not have the effect of changing LDL levels (Foster et al 2003). The ketogenic diet only had a very minimal effect on LDL levels (Westman et al 2008). Similar results were also found in other study that the ketogenic diet only provided insignificant changes in LDL levels (Chiu et al 2017). This was different from the results of a study conducted by Dashti et al (2004) which stated that after undergoing a long-term ketogenic diet program LDL levels in the sample decreased.

Other study had also compared the effects of changes in LDL levels before and after undergoing ketogenic therapy (Noain et al 2020, Burén et al 2021). The samples were given therapy in the form of a ketogenic diet for three months and six months, stating that the samples treated with the ketogenic diet for three months did not change their LDL levels, while the samples treated with the ketogenic diet for six months found an average decrease in LDL levels only around $.06 \mathrm{~nm}$ (Lima et al 2015).

The remaining particles from the formation of HDL were taken by the liver or converted to LDL. The reduced circulation of VLDL, especially in the postprandial period results in less transfer of cholesterol ester protein (CETP) - exchange of neural lipids with LDL-C. The reduction in hepatic lipase (HL) prevented a greater LDL-C from being converted to solid (atherogenic) LDL. This made the ketogenic diet in the short-term not too significant for LDL levels (Volek et al 2005).

\section{CONCLUSION}

High fat diet increased HDL and its increase occurred starting in high-fat diet with a proportion of $45 \%$ fat or more.

\section{ACKNOWLEDGMENT}

The authors thank all members at the Embryology laboratory for their technical assistance during the study. Besides, we thank to the Ministry of Research Technology and Higher Education of the Republic of Indonesia for the financial support in this study.

\section{REFERENCES}

Burén J, Ericsson M, Damasceno NRT, et al (2021). A ketogenic low-carbohydrate high-fat diet increases LDL cholesterol in healthy, young, normal-weight women: A randomized controlled feeding trial. Nutrients 13, 1-12.

Chiu S, Williams PT, Krauss RM (2017). Effects of a very high saturated fat diet on LDL particles in adults with atherogenic dyslipidemia: A randomized controlled trial. PLOS ONE 12, 1-14.

Dashti HM, Mathew TC, Hussein T, et al (2004). Longterm effects of a ketogenic diet in obese patients. Experimental and Clinical Cardiology 9, 2005.

Hu T, Yao L, Reynolds K, et al (2015). The effects of a low-carbohydrate diet vs. a low-fat diet on novel cardiovascular risk factors: A randomized controlled trial. Nutrients 7, 7978-94.

Jensen NJ, Wodschow HZ, Nilsson M, et al (2020). Effects of ketone bodies on brain metabolism and function in neurodegenerative diseases. International Journal of Molecular Sciences 21, 1-17. 
Kosinski C, Jornayvaz FR (2017). Effects of ketogenic diets on cardiovascular risk factors: Evidence from animal and human studies. Nutrients 9, 1-16.

Lima PA, de Brito SLP, Damasceno NRT (2015). Ketogenic diet in epileptic children: Impact on lipoproteins and oxidative stress. Nutr. Neurosci 18, 337-344.

Masood W, Annamaraju P, Uppaluri KR (2020). Ketegonic diet. Treasure Islands (FL), StatPearls Publishing, p 1.

Ministry of Health (2013). Basic health research, Jakarta, Balitbang Kemenkes RI.

Noain JS, Minupuri A, Kulkarni K, et al (2020). Significant impact of the ketogenic diet on lowdensity lipoprotein cholesterol levels. Cureus 12, 1-4.

Oyekale AS (2019). Effect of obesity and other risk factors onhypertension among women of reproductive age inghana: an instrumental variable probit model. International Journal of Environmental Research and Public Health, 16, 1-17.
Paoli A, Rubini A, Volek JS, et al (2013). Beyond weight loss: A review of the therapeutic uses of verylow-carbohydrate (ketogenic) diets. European Journal of Clinical Nutrition 67, 789-96.

Salvador AC, Arends D, Barrington WT, et al (2021). Sex-specific genetic architecture in response to American and ketogenic diets. International Journal of Obesity 45, 1-14.

Volek JS, Sharman MJ, Forsythe CE (2005). Modification of lipoproteins by very low-carbohydrate diets. J Nutr 2005, 6, 1339-1342.

Westman EC, Yancy WS, Mavropoulos JC, et al (2008). The effect of a low-carbohydrate, ketogenic diet versus a low-glycemic index diet on glycemic control in type 2 diabetes mellitus. Nutrition \& Metabolism 5, $1-9$. 